\title{
The Effect on Using Different Types of Electrodes toward the Tensile Strength of the Welding Joints Groove V Low Carbon Steel Type DIN 1.0038
}

\author{
Yogi Fernando, Rodesri Mulyadi \& Ambiyar \\ Jurusan Teknik Mesin, Fakultas Teknik, Universitas Negeri Padang, Indonesia
}

\begin{tabular}{l}
\hline Article Info \\
\hline Article history: \\
Received Jun $03^{\text {th }}, 201 \mathrm{x}$ \\
Revised Aug $09^{\text {th }}, 201 \mathrm{x}$ \\
Accepted Nov $11^{\text {th }}, 201 \mathrm{x}$ \\
\hline Keywords \\
Tensile Strength \\
SMAW Welding \\
V Groove \\
Low Carbon Steel \\
E 6013 \\
\hline
\end{tabular}

\begin{abstract}
The choice of electrode type in welding will affect the strength of the welding result. The aim of this study was to determine the effect on using different type of electrode on the tensile strength of low carbon steel type 1.0038 by using experimental method. The welding was conducted using Groove V. In addition, the specimens used in this research were the low carbon steel plate type 1.0038 with a thickness of $8 \mathrm{~mm}$ and were given SMAW treatment using 2 different types of electrodes, namely E 6013 and E 7016 whose diameters were 2.6 and $3.2 \mathrm{~mm}$. The standard specimen used was ASTM-E8 and being tested using a Universal Testing Machine. Based on the research that had been conducted, it was obtained that the steel type 1.0038 welded using $E 7016$ electrodes had a higher tensile strength than the one using E 6013.
\end{abstract}

\section{Corresponding Author:}

Yogi Fernando,

Jurusan Teknik Mesin, Fakultas Teknik, Universitas Negeri Padang

Jln. Prof. Dr. Hamka Air Tawar, Padang (25131), Sumatera Barat, Indonesia

Email: yogifernando1998@gmail.com

\section{INTRODUCTION}

Welding technology has been widely used in joining rods on the steel building construction and construction of machine components. Using welded joints is much lighter and the manufacturing process is simple, resulting in lower overall costs. In addition, the welding process can also be used to repair filling holes in castings, make a hard coating on tool surfaces, rebuild worn parts and repair other engine components [1]. Welding production factors consist of the manufacturing schedule, tools, and materials required, the sequence of execution, welding preparation (including: welding machine selection, welder appointment, electrode selection, the use of seam type) [2]. As a matter of fact, Low-carbon steels have good weld ability compared to medium-carbon and high-carbon steels. Welding cracks in steel can occur easily on the thick plates welding or if the steel contains the excessive amount of free sulfur [3]. Testing the strength of the welding results is carried out by tensile testing by giving a tensile load to the test rod slowly until it breaks by measuring the creep limit, tensile strength, elongation, and area reduction [4]. Thus, SMAW welding will later be used to conduct research using 2 types of electrodes, namely E 7016 electrodes and E 6013 electrodes as a form of comparison of the effectiveness of the results of the tensile strength of the two types of welding carried out.

As a matter of fact, the quality of welding is mainly determined by several factorssuch as the position of the weld, the joined metal material, the effect of heat, the type of seam, and the type of electrode used [5]. The use of different electrodes in welding will result in a different chemical composition of the weld metal, as well as a different weld metal structure and HAZ (Heated Affected Zone), so that the strength of the weld metal from the welding results using these electrodes is also different [6]. The tensile test is a type of destructive test [7]. This type of testing is carried out on the test object until it breaks [8]. Tensile testing is a test that is carried out by applying an axial load to the material until it is broken [9]. Additionally, if an object is given a pull force then the object will experience a length extension which is caused by a relationship between the attractive force application and the increase in length [10].

The working principle of the tensile test is carried out using a static load that is given gradually until the test object breaks. Several mechanical properties obtained from the tensile test results are tensile strength, brittleness, and ductility. These properties can be obtained from the stress-strain curve of the tensile test carried 
out by the process of drawing the material to break [11]. This study is a continuation of the research by Azwinur [12] who conducted a research on the effect of different types of electrodes on the mechanical properties of SS 400 material which resulted in welding using E 7018 electrodes producing greater tensile strength followed by welding with E 7016 electrodes and electrode E 7010-P1. Hence, by comparing the welding results with the type of electrode used, it can be a reference in attaining the effectiveness of using the right electrode for a particular material, like the research conducted by Shomad [13] on the analysis of the effect of variations in welding electrodes E 6013 and E 7018 on tensile strength and the hardness of the SS400 steel material which identifies that the $\mathrm{E} 7018$ electrode variation group has the strongest result of $422.08 \mathrm{~N} / \mathrm{mm}^{2}$. Likewise, Arifin [14] also studied the effect of electrode type on mechanical properties SMAW welding results ASTM A36 steel with a weld using electrodes E 6013 tensile strength values and it was obtained that $34.697 \mathrm{~N} / \mathrm{mm}^{2}$ was much better than the use of electrodes E 7016 and E 7018.

In short, the use of the suitable electrode can affect the strength of the welding joint [15]. Each electrode has different mechanical properties [16]. In addition, SMAW welding is also influenced by the chemical composition of the electrodes which produces a protective gas to protect metal liquids from outdoor air [17]. Furthermore, the chemical composition can affect the strength and toughness of the weld [18]. The purpose of this study is to determine the suitability between the use of the electrode type and the material used in SMAW welding so that it can obtain good tensile strength results in which it can be a reference in SMAW welding work.

\section{METHOD}

The method used in this study was an experimental research method in which the method was applied to find the effect of a particular treatments on others under a controlled circumstance [19]. In addition, the object of this research was welding carbon steel plate type 1.0038 with a thickness of $8 \mathrm{~mm}$ as a result of SMAW welding with electrodes E 7016 and E $6013 \varnothing 3.2 \mathrm{~m}$ where the treatment given was to provide two types of electrodes, E 7016, and E 6013.

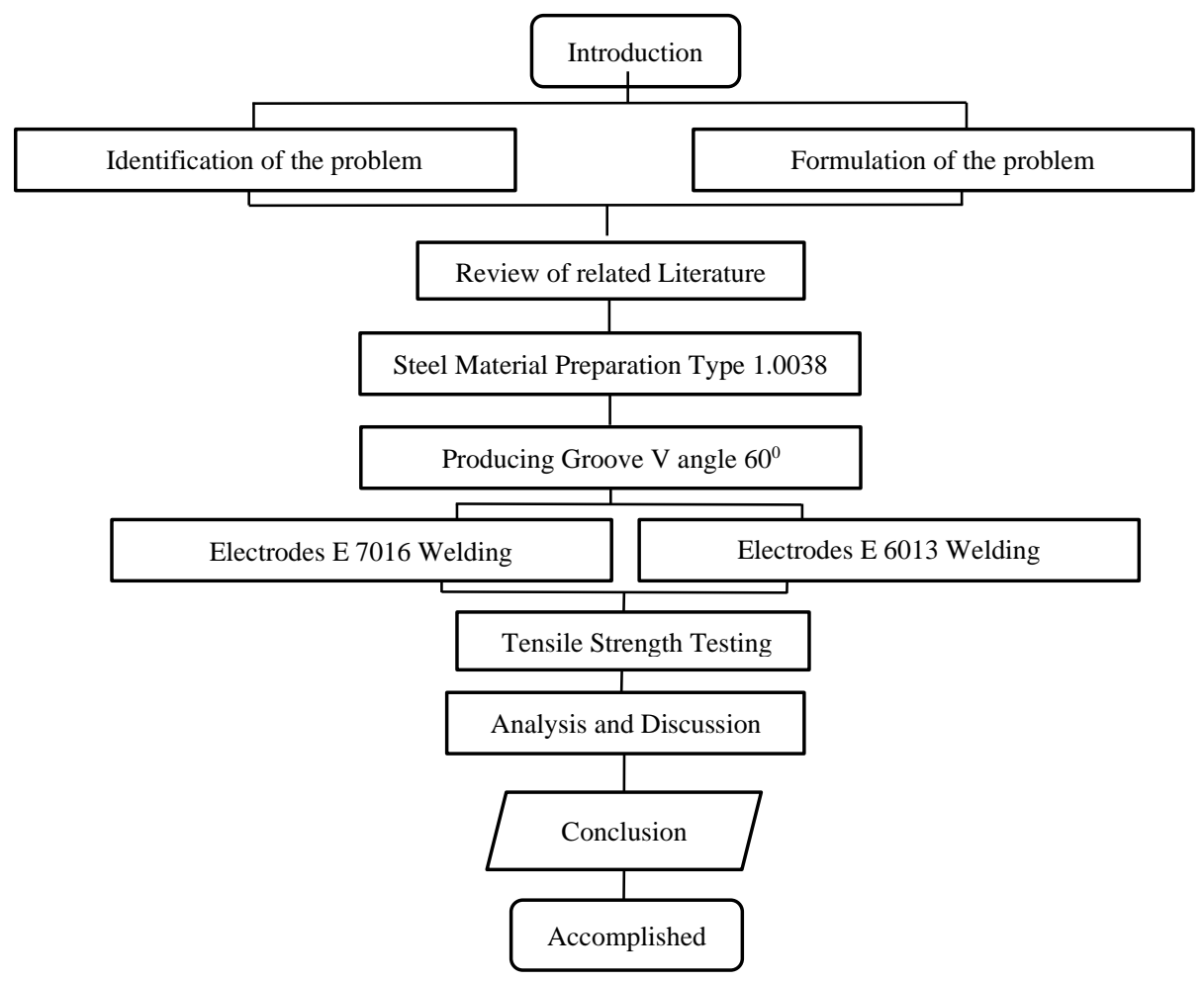

Figure 1 : Research Flowchart

In fact, the tensile testing was conducted 3 times for each specimen by using the Universal Testing Machine with specifications as shown in table 1. 
Table 1 : Tensile Testing Machine Specifications

\begin{tabular}{cc}
\hline Type & WAW-10000 \\
\hline Year & 2019 \\
Made in & China \\
Capacity & $1000 \mathrm{KN}$ \\
No. Serial & 180045 \\
\hline
\end{tabular}

As a matter of fact, the variables in this study consisted of dependent variables and independent variables. The dependent variable group in this study consisted of steel type 1.0038 , Flow $80 \mathrm{~A}$, seam V, and specimen standard ASTM-E8. Meanwhile, the independent variable group consisted of E 7016 electrode and E 6013 electrodes which was illustrated in Figure 2.

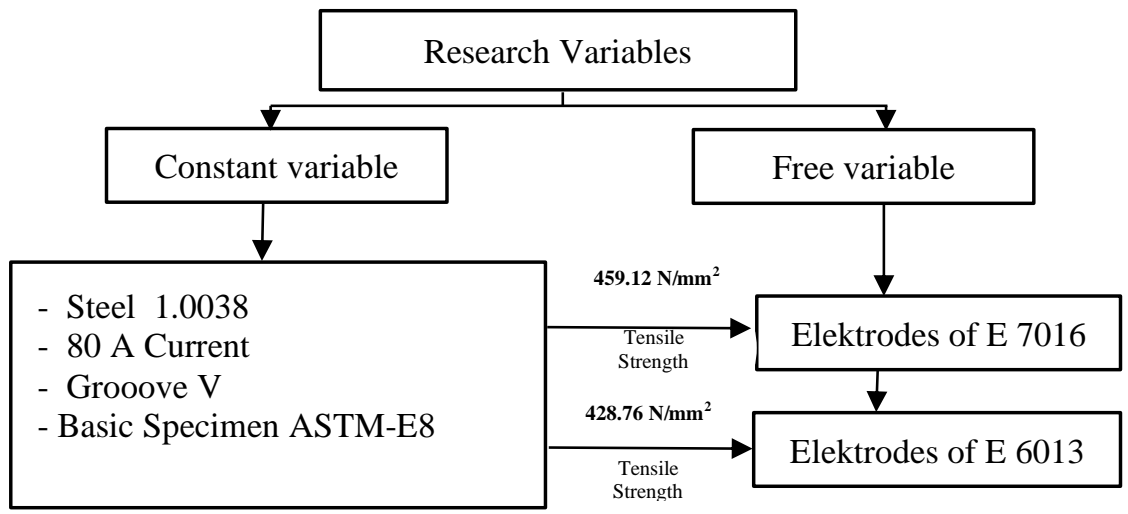

Figure 2 : Research Variables

The welding joints used in this study were open V-shaped joints with an angle of $60^{\circ}$ (Figure 3 ). Here, the seam connection $\mathrm{V}$ was used to join metal or plates with a thickness of 6-20 $\mathrm{mm}$ with a seam angle of $50^{\circ}$, a root distance of 0-2 $\mathrm{mm}$ and a root height of $0-3 \mathrm{~mm}$. The welding was carried out in accordance with the Welding Procedure Specification (WPS).
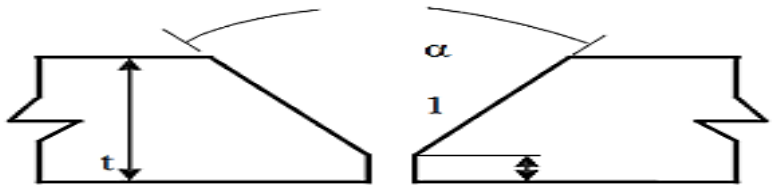

Figure 3 : V ASTM E8 Adjoining [20].

A single $\mathrm{V}$ groove joint was able to withstand pressure much better than other sorts of joints [21]. Furthermore, the penetration depth increases with the rise of welding current [22]. The choice of connection type was undeniably crucial and should be selected based on its needs and uses [23]. The shape of the test specimens that was used in the tensile test was the ASTM E8 standard as illustrated in Figure 4.

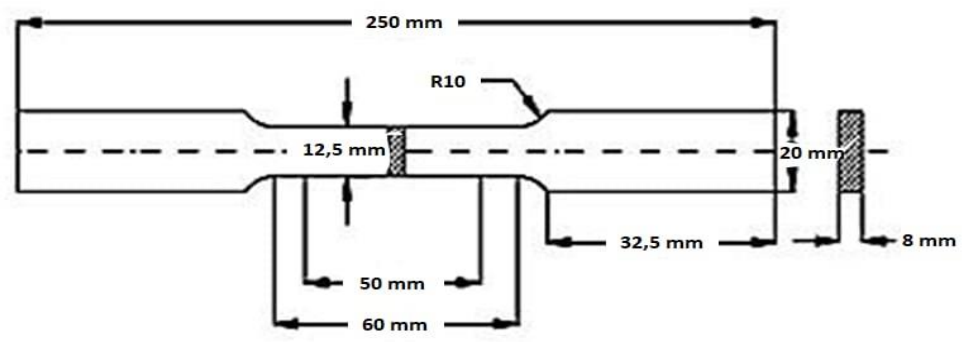

Figure 4 : Dimensions of the ASTM E8 Tensile Test Specimen [24] 
During the tensile test, the load was given continuously, slowly and constantly. At the same time, the elongation experienced by the test object was thoroughly observed and then, a stress-strain curve was generated. Therefore, to obtain the value of the tensile strength of the material $(\sigma)$, the value of the maximum force $(\mathrm{F})$ was divided by the cross-sectional area $\left(\mathrm{A}_{0}\right)$ (Equation 1) [25]. After attaining the tensile strength value, then the next was to obtain the strain value $(\varepsilon)$ in which the final length of the material obtaining after the testing $\left(\mathrm{L}_{\mathrm{i}}\right)$ minus the initial length of the material before the tensile test $\left(\mathrm{L}_{0}\right)$, then divided it with the length of the initial material $\left(\mathrm{L}_{0}\right)$ then multiplied by $100 \%$ (Equation 2) [25]. Finally, to determine the value of the modulus of elasticity of the material $(\mathrm{E})$, the amount of tensile strength $(\sigma)$ was divided by the strain that occurred in the material ( $\varepsilon$ ) (Equation 3) [26].

$$
\begin{aligned}
& \sigma=\frac{F \mathrm{~m}}{A_{0}} \ldots \ldots \ldots \ldots \ldots \ldots \\
& \varepsilon=\frac{L_{i-L_{0}}}{L_{0}} \times 100 \% \\
& E=\frac{\sigma}{\varepsilon} \ldots \ldots \ldots \ldots \ldots
\end{aligned}
$$

\section{RESULTS AND DISCUSSION}

The results of the tensile test were obtained after testing the whole nine specimens test. In that case, Figure 5 was the result of the tensile test of each damaged specimen with a breaking point on the based metal.

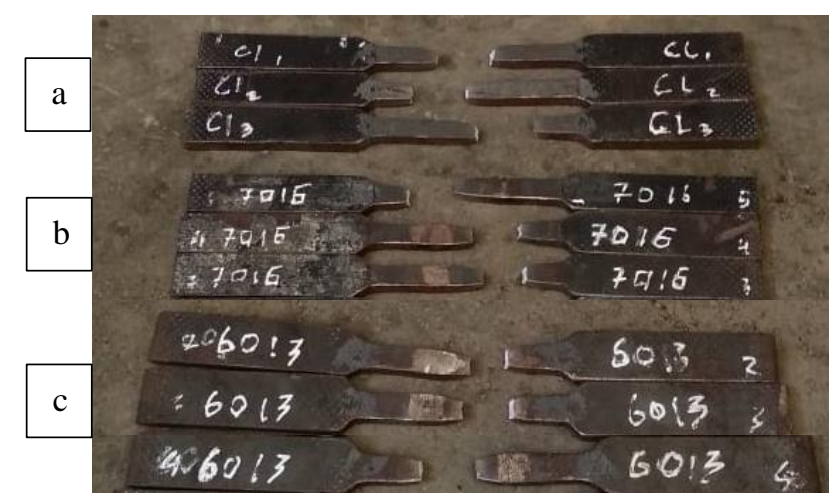

Figure 5 : Specimens Tensile Test after Testing

In addition, Figure 5 shows the specimens after the tensile testing, image (a) the control specimens type of 1.0038 steel without SMAW welding heat treatment, image (b) test specimens with SMAW welding heat treatment using electrode E 7016, and image (c) test specimens with SMAW welding heat treatment using E 6013 electrodes. table 2 :

Based on the results of the tensile test that has been conducted, the average results of the test is written in

Table 2: Average results of the tensile test

\begin{tabular}{ccccc}
\hline \multirow{2}{*}{ Tensile Strength } & \multicolumn{4}{c}{ Spesimen $\left(\mathrm{N} / \mathrm{mm}^{2}\right)$} \\
\cline { 2 - 5 } & 1 & 2 & 3 & Average \\
\hline Steel Type 1.0038 & 441 & 455 & 443,2 & $\mathbf{4 4 6 , 4 0}$ \\
E 7016 & 468,4 & 443 & 457,4 & $\mathbf{4 5 6 , 2 7}$ \\
E 6013 & 442,6 & 442 & 431,2 & $\mathbf{4 3 8 , 6 0}$ \\
\hline
\end{tabular}


The tensile test results show that the average test results on the control specimens was $446.40 \mathrm{~N} / \mathrm{mm}^{2}$. On specimens with welding electrodes $\mathrm{E} 7016$, the result was $456.27 \mathrm{~N} / \mathrm{mm}^{2}$. Last, on specimens with welding electrodes E 6013, it resulted on $438.60 \mathrm{~N} / \mathrm{mm}^{2}$. Hence, based on the table of the average tensile test results above, the comparison of results among the control specimens, SMAW welding using E 7016 electrodes, and SMAW welding using E 6013 electrodes can be seen significantly, as shown in Figure 6.

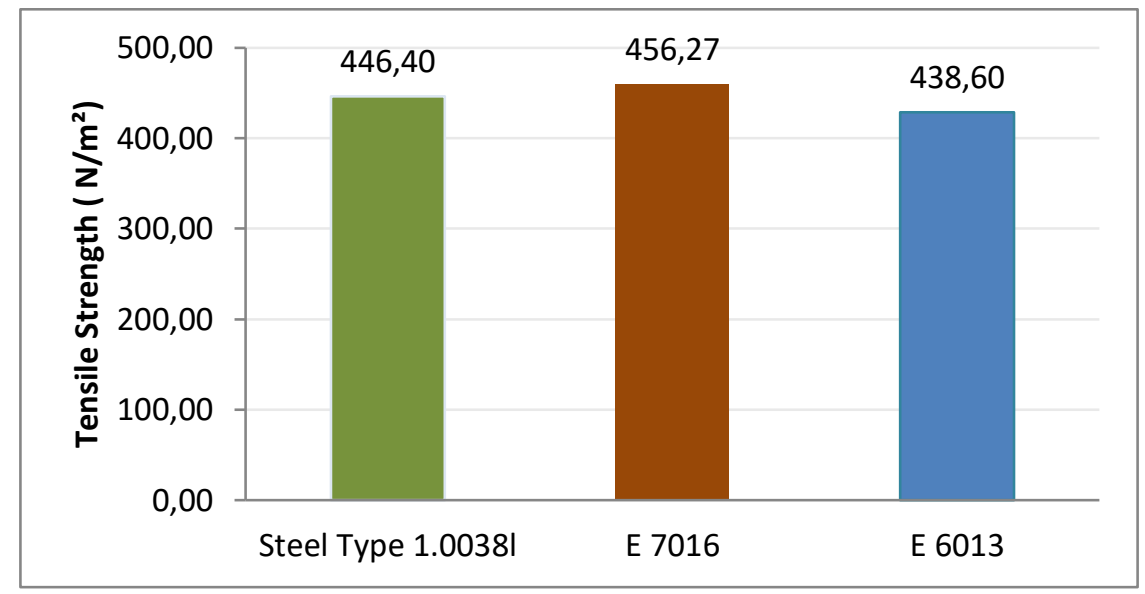

Figure 6 : Comparison of Graph of the Results on the Tensile Strength of the Specimen

Based on the results of the analysis on the tensile test data, the average value of the SMAW welding pressure using the E 7016 electrode was $456.27 \mathrm{~N} / \mathrm{m}^{2}$ which was higher than the average stress value of the control specimen of $446.40 \mathrm{~N} / \mathrm{m}^{2}$, and the SMAW E 6013 welding at $438.60 \mathrm{~N} / \mathrm{m}^{2}$. Notably, for the average strain value in SMAW welding using E 7016 electrodes, the strain percentage was obtained at $23.52 \%$. In fact, it was higher than the SMAW welding using E 6013 electrodes which was only $18.44 \%$, and it was much lower than the percentage of the raw material strain which was $31.73 \%$. For the average modulus of elasticity in SMAW welding using E 7016 electrodes, the result was $1.97 \mathrm{Gpa}$ which was lower than the average modulus elasticity of SMAW welding using E 6013 electrodes at $2.64 \mathrm{Gpa}$. On the other hand, it was higher than the average of the modulus elasticity of the raw material which was only $1.41 \mathrm{Gpa}$.

Based on the results of the analysis on the tensile test data, the average value of the SMAW welding pressure using the E 7016 electrode was $456.27 \mathrm{~N} / \mathrm{m}^{2}$ which was higher than the average stress value of the control specimen of $446.40 \mathrm{~N} / \mathrm{m}^{2}$, and the SMAW E 6013 welding at $438.60 \mathrm{~N} / \mathrm{m}^{2}$. Notably, for the average strain value in SMAW welding using E 7016 electrodes, the strain percentage was obtained at $23.52 \%$. In fact, it was higher than the SMAW welding using E 6013 electrodes which was only $18.44 \%$, and it was much lower than the percentage of the raw material strain which was $31.73 \%$. For the average modulus of elasticity in SMAW welding using E 7016 electrodes, the result was $1.97 \mathrm{Gpa}$ which was lower than the average modulus elasticity of SMAW welding using E 6013 electrodes at $2.64 \mathrm{Gpa}$. On the other hand, it was higher than the average of the modulus elasticity of the raw material which was only $1.41 \mathrm{Gpa}$.

Meanwhile the 1, 0038 steel specimens that did not undergo the heat treatment during the welding process were used as the control specimens. In particular, the control specimen had an average tensile strength value of $446.40 \mathrm{~N} / \mathrm{mm}^{2}$ where the control specimen did not experience any structural changes. On the other hand, on the specimen which underwent a heat treatment in the first place, the SMAW welding process was conducted by using E 7016 electrodes, and based on the results of the tensile strength test, the specimen broke on the base metal. As a matter of fact, this specimen generated the highest tensile strength among the whole tensile test specimens with an average tensile strength value of $456.27 \mathrm{~N} / \mathrm{mm}^{2}$. The use of this type of electrode is very suitable for SMAW welding of 1.0038 type carbon steel. Additionally, toward the specimens with the second heat treatment, SMAW welding was carried out using E 6013 electrodes. From the results of the tensile strength test, the specimens broke on the base metal. This specimen generated an average tensile strength value of $438.60 \mathrm{~N} / \mathrm{mm}^{2}$. It can be concluded that the use of this type of electrode is less suitable for SMAW welding of 1,0038 using carbon steel because it produces the lowest average tensile strength compared to all tensile test specimens. 


\section{CONCLUSION}

Based on the research that had been conducted, it can be concluded that SMAW welding using steel type of 1.0038 by using electrodes E 7016 had a stronger tensile strength by producing a tensile stress value of $456.27 \mathrm{~N} / \mathrm{m}^{2}$ compared to SMAW welding using E 6013 electrodes which was only able to generate a voltage value of $438.60 \mathrm{~N} / \mathrm{m}^{2}$. The comparison of the difference in tensile strength values between control specimens and SMAW welding using E 7016 electrodes was $9.87 \mathrm{~N} / \mathrm{mm}^{2}$ and the control specimens with SMAW welding using E 6013 electrodes was $7.8 \mathrm{~N} / \mathrm{mm}^{2}$. Meanwhile, the use of both types of electrodes against Carbon steel type 1.0038 was considered suitable. In fact, this is well proved when the whole test specimens broke on the base metal. In short, the best tensile strength was SMAW welding using E 7016 electrodes which functioned as the comparison that this sort of electrode has widely affected the tensile strength on the carbon steel 1.0038.

\section{REFERENCES}

[1] P. T. Iswanto and R. A. Himarosa. Karakterisasi Sambungan SMAW Baja Karbon Rendah Menggunakan 3 Jenis Elektroda. Jurnal Material dan Proses Manufaktur. 2017; 1 (2): 103-109.

[2] H. Wiryosumarto. Teknologi Pengelasan Logam. Jakarta: Pradnya Paramita. 1988.

[3] I. Katulistiwa and Yunus. Pengaruh Variasi Besar Arus Pengelasan dan Jenis Elektroda Las TIG ( Tungsten Innert Gas) Pada Baja Karbon Rendah Terhadap Kekuatan Tarik dan Bending. Jurnal Teknik Mesin. 2014; 2 (2): 61-69.

[4] A. S. Kurniawan, Solichin, and R. P. Puspitasari. Analisis Kekuatan Tarik Dan Struktur Mikro Pada Baja St.41 Akibat Perbedaan Ayunan Elektroda Pengelasan SMAW. Jurnal Teknik Mesin. 2014; 22 (2): $1-12$.

[5] Daryanto. Teknik Las. Bandung: Alfabeta. 2012.

[6] D. Suresh Kumar and P. Srikar. A Review on Comparison of Mechanical Properties of Dissimilar Steels Welded by TIG and MIG. E3S Web of Conferences. 2020; 184: 1-6.

[7] A. A. Nassar, R. M.Lefta, and M. J. Abdulsada. Eksperimental Study Of The Effect Of Weldig Elctrode Types On Tensile Properties Of Low Carbon Steel AISI1010. Kufa Jornal of Engineering. 2018; 9 (4): 163-167.

[8] D. Sumardianto and S. Susilowati. Effect of Welding Parameters on Mechanical Properties of Low Carbon Steel API 5L Shielded Metal Arc Welds. American Journal of Material Science. 2019; 2 (25): 15-21.

[9] S. V. Lomov et al. Experimental methodology of study of damage initiation and development in textile composites in uniaxial tensile test. Composites Science and Technology. 2008; 68 (12): 2340-2349.

[10] H. Istiqlaliyah and A. Mufarrih. Analisa pengaruh variasi kuat arus, media pendingin, dan merk elektroda terhadap kekuatan tarik dan distorsi sudut sambungan baja st 37. Jurnal Teknik Mesin Indonesia. 2018; 11 (1): 41-45.

[11] H. Wiryosumarto and T. Okumura. Teknologi pengelasan logam. Jakarta: Pradnya Paramita. 2008.

[12] Azwinur and Muhazir. Pengaruh Jenis Elektroda Pengelasan SMAW Terhadap Sifat Mekanik Material SS400. Jurnal Polimesin. 2019; 17 (1): 19-25.

[13] M. A. Shomad and M. Shahar Mushfi. Analisis pengaruh variasi elektroda las e6013 dan e7018 terhadap kekuatan tarik dan kekerasan pada bahan baja ss 400. Dinamika Teknik Mesin. 2017; 7 (2): 73-79.

[14] J. Arifin, H. Purwanto, and I. Syafa'at. Pengaruh Jenis Elektroda Terhadap Sifat Mekanik Hasil Pengelasan Smaw Baja Astm a36. Jurnal Momentum UNWAHAS. 2017; 13 (1): 27-31.

[15] A. Novendra, R. Refdinal, and S. K. Le. Hardness Analysis of Stone Breaker Chisel Made of Medium Carbon Steel as a Result of Hardening Using Water Cooling Media. Teknomekanik. 2020; 3 (1): 22-27

[16] D. W. Cho, S. J. Na, M. H. Cho, and J. S. Lee. A study on V-groove GMAW for various welding positions. Journal of Materials Processing Technology. 2013; 213: 1640-1652.

[17] Satoh and M.Toyoda. Joint Strength of Heavy Plates with Lower Strength Weld Metal Tests. Welding Reserch Supplement. 1975; 311-320.

[18] A. J. M. Gomes, J. C. F. Jorge, L. F. G. de Souza, and I. de Souza Bott. Influence of chemical composition and post welding heat treatment on the microstructure and mechanical properties of high strength steel weld metals. Materials Science Forum. 2013; 758: 21-31.

[19] Sugiyono. Metode Penelitian Kuantitatif Kualitatifdan R\&D. Bandung: Alfabeta. 2008: 72.

[20] M. Bin Afan, P. Purwantono, M. Mulianti, and B. Rahim. Pengaruh Suhu Penyimpanan Elektroda Low Hydrogen E7016 terhadap Hasil Uji Tekuk Sambungan Las Pelat Baja Karbon SS400. Jurnal Rekayasa Mesin. 2020; 15 (1): 20-25. 
[21] P. Taylor, N. E. İ, and F. Elaldi. Materials and Manufacturing Processes Analysis of Welding Groove Angle and Geometry on Strength of Armor Steel Analysis of Welding Groove Angle and Geometry on Strength of Armor Steel. Material and Manufacturing Processes. 2012; 27: 1437-1441.

[22] E. Karadeniz, U.Ozsarac, and C.Yildiz. Influence of different initial microstructure on the process of spheroidization in cold forging. Materials and Design. 2007; 28: 649-656.

[23] M. Q. Johnson, G. R. Edwards, and G. M. Evans. The Influence of Titanium Additions and Interpass Temperature on the Microstructures and Mechanical Properties of High Strength SMA Weld Metals. ISIJ International. 1995; 35 (10): 1222-1231.

[24] M. A. Pratomo, J. Jasman, N. Erizon, and Y. Fernanda. The Variation Effect of Electric Current Toward Tensile Strength on Low Carbon Steel Welding with Electrode E7018. Teknomekanik. 2020; 3 (1): 916.

[25] Bondan T. Sofyan. Pengantar Material Teknik. Jakarta: Salemba Teknika. 2010: 27.

[26] D. Groenendijk.G, dkk. Pengujian Material. Belanda. 1984: 25

\section{NOMENCLATURE}

The meanings of the symbols used in this equation are as follow :

$\begin{array}{ll}\sigma & \text { meaning of maximum tensile strength } \\ \text { Fm } & \text { meaning of maximum tensile force } \\ \text { Ao } & \text { meaning of cross-sectional area } \\ \varepsilon & \text { meaning of strain } \\ \mathrm{Li} & \text { meaning of length of the specimen after testing } \\ \mathrm{Lo} & \text { meaning of length of the specimen before testing } \\ \mathrm{E} & \text { meaning of the modulus of elasticity }\end{array}$

